\title{
NEW SPECIES OF PORROGLOSSUM (ORCHIDACEAE: PLEUROTHALLIDINAE) FROM ECUADOR
}

\author{
Gilberto Merino $^{1}$, Alfonso Doucette $^{1,2} \&$ Franco Pupulin $^{1,3-6}$ \\ 'Centro de Investigación en Orquídeas de los Andes "Ángel Andreetta", \\ Universidad Alfredo Pérez Guerrero, Ecuador \\ ${ }^{2}$ Plant Sciences Department, Cornell University, Ithaca, New York, U.S.A. \\ ${ }^{3}$ Jardín Botánico Lankester, University of Costa Rica. \\ ${ }^{4}$ Harvard University Herbaria , Cambridge, Massachusetts, U.S.A \\ ${ }^{5}$ Marie Selby Botanical Gardens, Sarasota, Florida, U.S.A \\ ${ }^{6}$ Corresponding author: fpupulin@cariari.ucr.ac.cr
}

\begin{abstract}
Three new species of Porroglossum from Ecuador are described and illustrated. Porroglossum miguelangelii is compared to the Peruvian P. lycinum, from which it differs by the longer, narrower petals with margins that are not obtusely angled below the middle and the presence of stigmatic tooth-like processes. Porroglossum merinoi is distinctive in that it is the only species with densely pubescent sepals. Porroglossum porphyreum is similar to $P$. schramii, but differs in the sepals with a thickened tail abruptly inserted at their apex, the petals with teeth on both the upper and lower margin, and the labellum provided with a longer and broader basal callus.
\end{abstract}

Kew words: Orchidaceae, Pleurothallidinae, Porroglossum, P. miguelangelii, P. merinoi, P. porphyreum, Ecuador, new species

Introduction. The genus Porroglossum Schltr. (Orchidaceae) includes 38 species restricted to Andean South America, where they range from Venezuela to Peru (Luer 1987). Ecuador is the genus's center of diversity with 23 species recorded (Dodson 2004). With 8 species, Colombia has the second highest species concentration. The first species described, Porroglossum echidna (Rchb.f.) Garay, was discovered in Colombia and was attributed to the genus Masdevallia Ruiz \& Pav. based on its caespitose habit, short ramicauls, and sepals with long tails (Luer 1987). Rudolf Schlechter proposed the genus in 1920, based on $P$. colombianum [ $=P$. mordax (Rchb.f.) Sweet] and $P$. muscosum (Rchb.f.) Schltr., mainly distinguishing Porroglossum from Masdevallia by the apical position of the anther and the presence of a long column foot with a free apex (Schlechter 1920). The unusually long column foot in Porroglossum functions to accommodate the active mobility of the labellum. The region of the labellum that rests against the column foot is sensitive to tactile stimuli and responds to touch by relaxing the labellum's long strap-like claw. This allows the labellum to reflex backwards and (hypothetically) push the pollinator against the column (Bean 1887, Leavitt 1906, Luer 1987). Although the pollination system has been described in detail by Bean (1887), Oliver (1888) and Luer (1987), the specific pollinators and mechanism of the genus has not yet been recorded in nature.

Sensitive labella have evolved independently in other taxa of the subtribe Pleurothallidinae Lindl. (Luer 1987, 2000). Examples include Acostaea Schltr. and Condylago Luer species, now treated as members of the genus Specklinia Lindl., and Masdevallia teaguei Luer, which was once recognized as the monotypic genus Jostia Luer. The presence of an irritable lip was once thought to be a key character for generic circumscription. Recent phylogenetic analyses based on combined molecular evidence (Pridgeon et al. 2001) show that in some cases it is unsuitable as a character for generic 
circumscription within the Pleurothallidinae because it creates paraphyletic groups. In contrast, lip motility observed in the well supported monophyletic clade of Porroglossum can be considered a synapomorphy of the genus. Porroglossum is the only currently accepted and recognized genus in the Pleurothallidinae that can be characterized as a whole by the presence of actively motile labella.

The systematics of Porroglossum was treated by Sweet $(1970,1972)$ and by Luer (1987). Luer recognizes two subgenera, subgen. Eduardia Luer and subgen. Porroglossum. Subgenus Eduardia is characterized by a repent growth habit and a simultaneously flowered inflorescence. The subgenus Porroglossum is composed of three sections: section Echidnae (Rchb.f.) Luer which contains species characterized by peduncle indumentums, section Tortae Luer which contains species characterized by non-resupinate flowers, and section Porroglossum which contains the rest of the species (Luer 1987). The species described here all belong to the section Porroglossum.

Luer (1987) attributed twenty-seven species names to the genus Porroglossum, considering $P$. colombianum and $P$. xipheres to be synonyms of $P$. mordax and P. muscosum, respectively. Since then, Luer has authored and co-authored thirteen new species, bringing the number of species names attributed to Porroglossum to forty and the number of species to thirty-eight (Luer 1988, 1989, 1991, 1994, 1995, 1998, 2004, 2006a, 2006b). In Ecuador, 23 species of Porroglossum have been previously recorded, representing over two thirds of the known species. In preparing a systematic revision of the Ecuadorian species of Porroglossum, we found three species that present enough morphological differences from the previously described species to be confidently proposed as new to science.

Porroglossum miguelangelii G.Merino, A.Doucette \& Pupulin, sp. nov.

TYPE: Ecuador. Zamora Chinchipe: without specific locality, $1800 \mathrm{~m}$, collected by Hugo Medina, November 1993, cultivated by Ecuagenera Orchid Nursery in Gualaceo, flowered in cultivation, 20 July 2008, G. Merino 1 (holotype: QCNE; isotype: Andean Orchids Research Center (CIOA, by the initials in
Spanish), University Alfredo Pérez Guerrero, Spirit Collection No. 000845). Fig. 1, 4A.

A Porroglosso procul Luer foliis ellipticis obtusis, petalis lineari-ligulatis subfalcatis, in parte media leviter angustatis, lamina labelli late obtriagulariobcuneata marginibus lateralibus incurvatis recedit.

Herb epiphytic, caespitose, 4 to $8 \mathrm{~cm}$ tall. Roots flexuous, $1 \mathrm{~mm}$ in diameter. Ramicauls terete, erect, abbreviated, blackish at the base $1 \mathrm{~mm}$ long, enclosed by 2 to 3 tubular sheaths. Leaf coriaceous, spathulate, elliptical-obovate $2-4 \times 0.5-1.0 \mathrm{~cm}$, narrowed at the base into a conduplicate petiole $1.5-2.0 \mathrm{~cm}$ long. Inflorescence a congested, successively flowered raceme 8-10 cm long; the peduncle glabrous, 5.0-9.5 $\mathrm{cm}$ long. Floral bracts tubular, $4 \mathrm{~mm}$ long. Pedicel 5 $\mathrm{mm}$ long. Ovary terete, minutely verrucose, 6-sulcate, $5 \mathrm{~mm}$ long. Flowers resupinate, held erect, without a detectable fragrance, the dorsal sepal yellow-green suffused with brown, with three brown veins, the lateral sepals yellow-green, the petals translucent, amber with a brown mid-vein, the lip white, spotted with dark brown, the column greenish-white with a cream anther cap. Dorsal sepal broadly ovate, concave, tricarinate, 9.5-10.0 $\times 5.0 \mathrm{~mm}$, contracted into a thick, erect tail, connate to lateral sepals for about $3 \mathrm{~mm}$. Lateral sepals subrectangular, tricarinate, $10-11 \times 6 \mathrm{~mm}$ when spread, connate for about $4 \mathrm{~mm}$ to form a laterally compressed cup, contracted at apex into a thickened, horizontally outstretched tails. Petals linear-ligulate, the apex rounded and broader than middle portion, 6 x $1 \mathrm{~mm}$. Lip unlobed, obcuneate-obtriangular, 4 x 5 $\mathrm{mm}$ at its widest portion, hinged to the column foot by a short rectangular strap, motile, with a sulcus running from the apex to the center of the blade, with a basal low, broad callus. Column short, stout, semiterete, fleshy, to $3 \mathrm{~mm}$ long, with two tooth like processes near the stigma. Anther cap transversely ovate, obtuseapiculate. Pollinia droplet shapped, 2 in number, each with a glandular caudicle.

Eponymy: Named to the memory of Miguel Ángel Soto Arenas, in recognition of his outsantding contributions to the knowledge of orchids.

Distribution: Known only from southeastern Ecuador.

Habitat AND ECOlogy: Epiphytic in shade in premontane and lower montane cloud forests, usually 


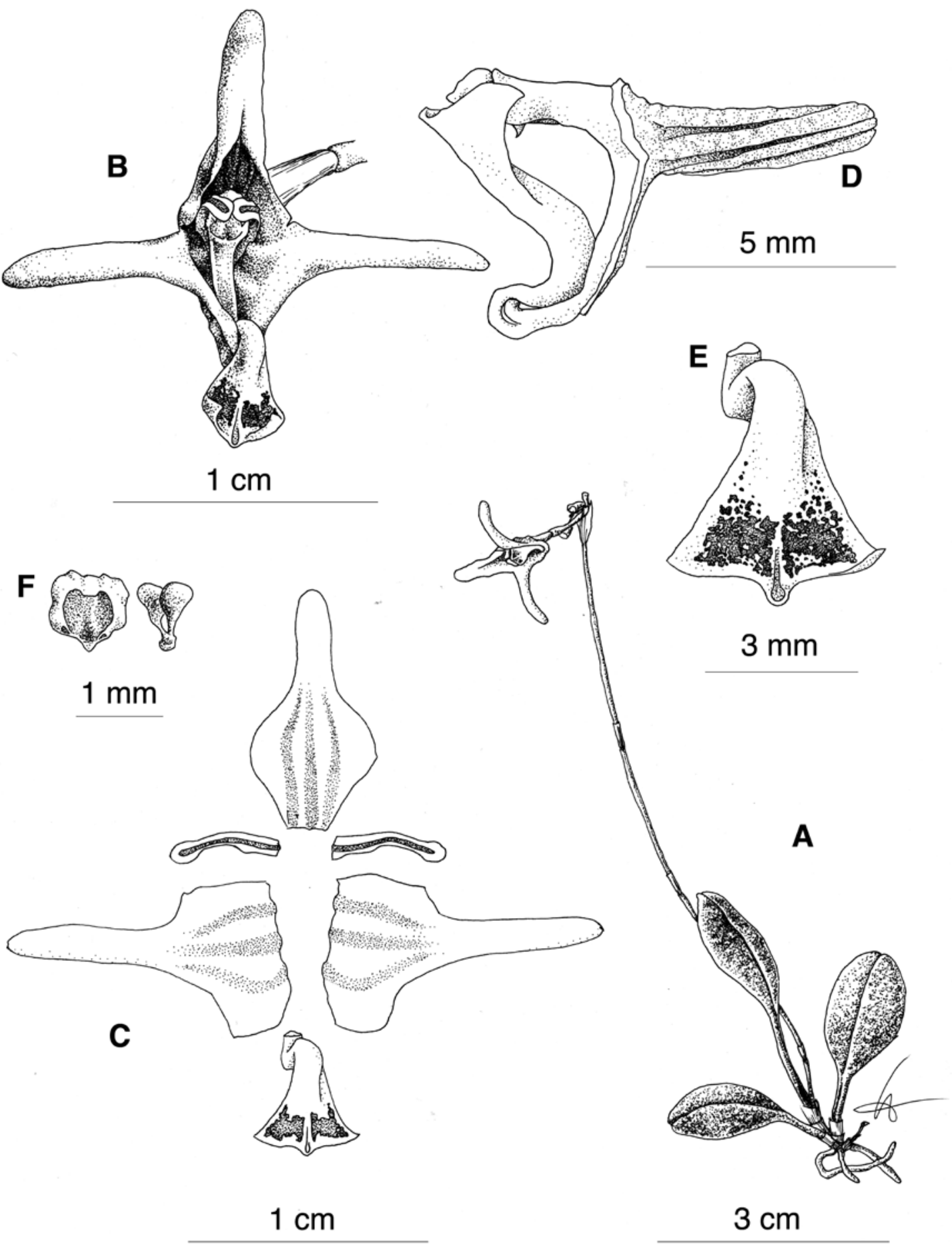

Figure 1. Porroglossum miguelangelii G.Merino, A.Doucette \& Pupulin. A — Habit. B — Flower. C — Dissected perianth. D - Column and lip, lateral view. E - Lip, spread. F - Anther cap and pollinarium. Drawn by A. Doucette from the holotype. 
in windy areas, at elevations of 1800 meters, where the plants mostly establish on small trees covered by mosses and lichens.

Porroglossum miguelangelii is most similar to $P$. lycinum Luer from northern Peru, from which it differs by smaller plants, the longer, narrower petals with margins that are not obtusely angled below the middle, the presence of tooth-like processes before the stigma (absent in P. lycinum), the spreading, pale green sepals, suffused with yellow at their apices (vs. projected forwards, speckled and suffused with brown in $P$. lycinum). The two species have similarly shaped labella that are both pale green and heavily flecked with dark purple towards their apex.

Porroglossum merinoi Pupulin \& A.Doucette, sp. nov.

TYPE: EcuAdOR. Morona-Santiago: Tumbez, $1200 \mathrm{~m}$, collected by Gilberto Merino, October 1993, flowered in cultivation, 12 June 2007, G. Merino 2 (holotype: QCNE; isotype: CIOA, Spirit Collection No. 000155). FIG. 2, 4B.

Species Porroglosso lycino Luer similis, floribus expansis sepalo superno reflexo, caudis sepalorum brevioribus ligulato-rotundatis, petalis ligulatis dente triangulari margine inferno instructis, labello obtrullato obtuso glabro differt.

Herb epiphytic, caespitose, to $6 \mathrm{~cm}$ tall. Roots flexuous, $1 \mathrm{~mm}$ diameter. Ramicauls erect, slender, 10--12 mm long, enclosed by 2 to 3 tubular, membranaeous sheaths that become papery with age. Leaf erect, coriaceous, long-petiolate, the blade elliptic-oblanceolate, sub-verrucose, 2.5-3.0 x 0.7-1.0 $\mathrm{cm}$, narrowed at the base into a conduplicate petiole 2.6-3.0 cm long. Inflorescence a suberect, congested, successively few-flowered raceme to $15 \mathrm{~cm}$ long; the peduncle terete, slender, glabrous, provided with 4-5 widely spaced, tubular bracts to $7 \mathrm{~mm}$ long. Floral bract tubular, $5 \mathrm{~mm}$ long. Pedicel terete, 7-8 $\mathrm{mm}$ long. Ovary terete, subverrucose, $5 \mathrm{~mm}$ long. Flowers resupinate, partially spreading, lightly fragrant of cloves, the sepals greenish yellow, pubescent, flushed with solid yellow at the glabrous apexes, the nerves yellow, the dorsal sepal with a central, purplish flush at the base; the petals translucent yellowish white, with a central stripe and the apex purple-red; the lip yellow, finely spotted with red; the column purple, with a yellowish white anther cap. Dorsal sepal lanceolate, narrowly obtuse, tricarinate, concave at the base, parallel to the column below the middle and gently deflexed above the middle, $6 \times 3 \mathrm{~mm}$, connate to the lateral sepals for about $1.5 \mathrm{~mm}$ to form a slightly, laterally-compressed cup. Lateral sepals transversely obtrapezoidal, 3-veined, narrowed at the middle into thick, ligulate, narrowly obtuse-rounded, forwardly directed tails, $7.5 \mathrm{~mm}$ long $\mathrm{x} 8 \mathrm{~mm}$ at its widest portion when spread, basally connate for about $1.5 \mathrm{~mm}$ to the dorsal sepal, connate to each other and to the column foot about $5 \mathrm{~mm}$ to form a deep, subacute, rounded chin. Petals subfalcate, 1-nerved, the lower margin with a triangular tooth below the middle, rounded at apex $4.0 \times 1.3 \mathrm{~mm}$, Lip long-unguiculate, the blade obcuneate-spathulate, broadly obtuse, with a short, sulcate, rounded apiculum, $5.5 \mathrm{~mm}$ long x $3 \mathrm{~mm}$ at its widest portion, thickened at the base into the straplike claw, bent with tension toward the free apex of the column-foot. Column semiterete, truncate, $2.5 \mathrm{~mm}$ long, with narrowly triangular-subfalcate, descending substigmatic arms, produced at the base into a slender, curved foot about $6 \mathrm{~mm}$ long; the anther terminal, incumbent. Anther cap transversely ovate, obtuseapiculate. Pollinia droplet shapped, 2 in number, each with a glandular caudicle.

Eponymy: Named after Gilberto Merino, Ecuadorean orchid researcher with a strong interest in Pleurothallidinae, who first collected this species.

Distribution: Collected once, known only from southeastern Ecuador.

Habitat AND ECology: The type specimen of P. merinoi was found growing as a shade epiphyte on a small tree covered by mosses, in cloud forest at about $1800 \mathrm{~m}$ of elevation. In cultivation, it flowers from May to June.

Porroglossum merinoi is one of the most distinctive species in the genus. It is the only species with truly pubescent sepals. P. hirtzii bears minute hairs on its sepals but they are sparsely distributed. $P$. merinoi is allied to $P$. andreettae, from which it differs by the petals with entire margins (vs. contracted into acute apices near the middle), a slightly broader labellum, and puberulent sepals provided with a thickened, glabrous, yellow apex. Both species are lightly fragrant. 


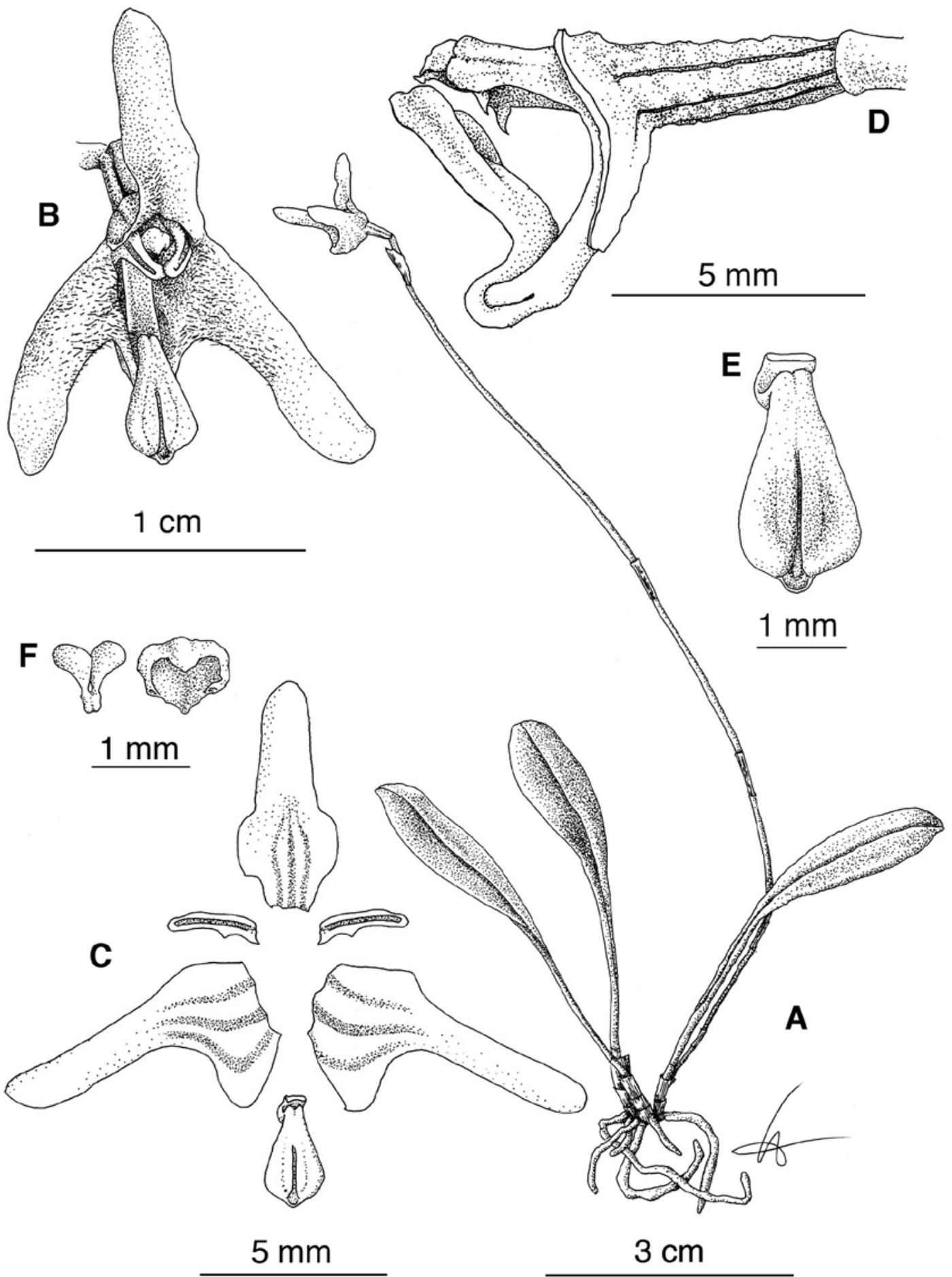

FiguRe 2. Porroglossum merinoi Pupulin \& A.Doucette. A - Habit. B - Flower. C - Dissected perianth. D - Column and lip, lateral view. E - Lip, spread. F - Pollinarium and anther cap. Drawn by A. Doucette from the holotype. 

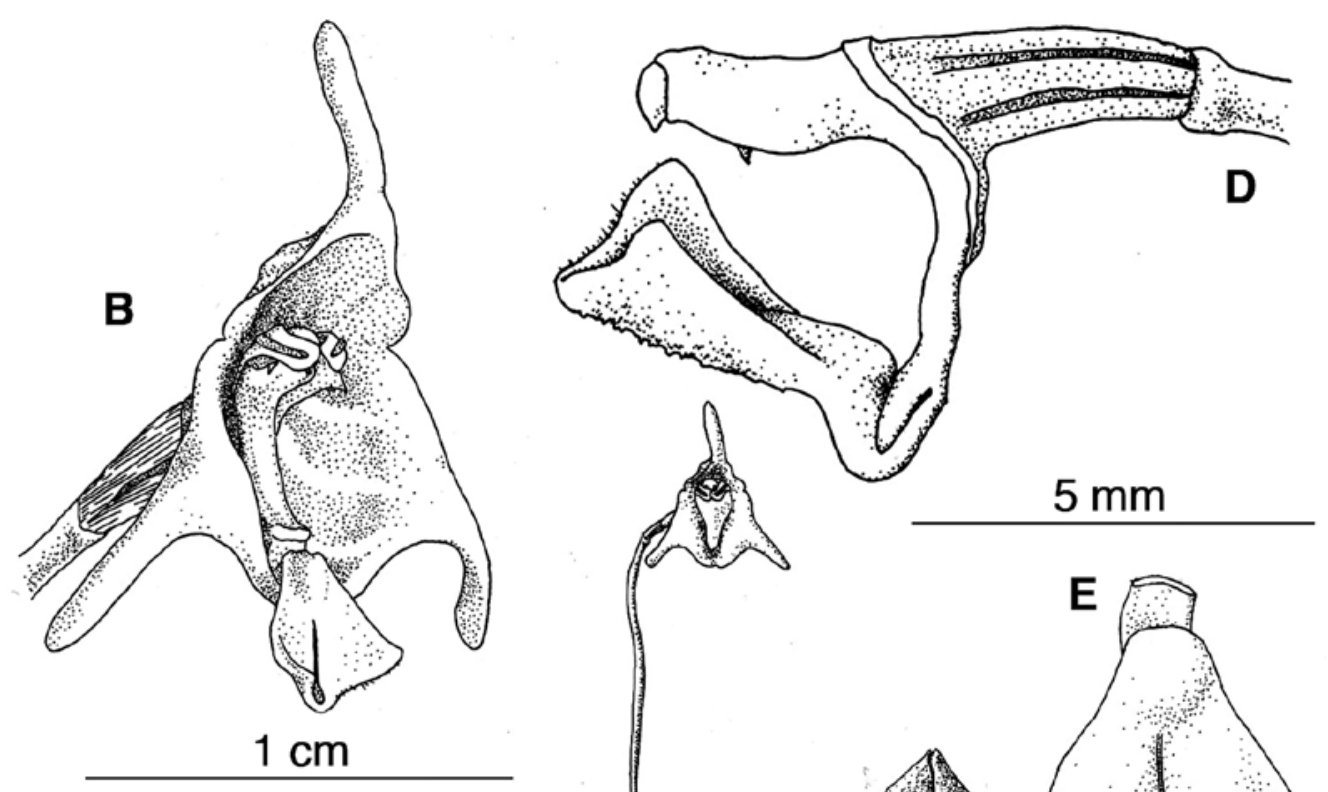

$F$ in
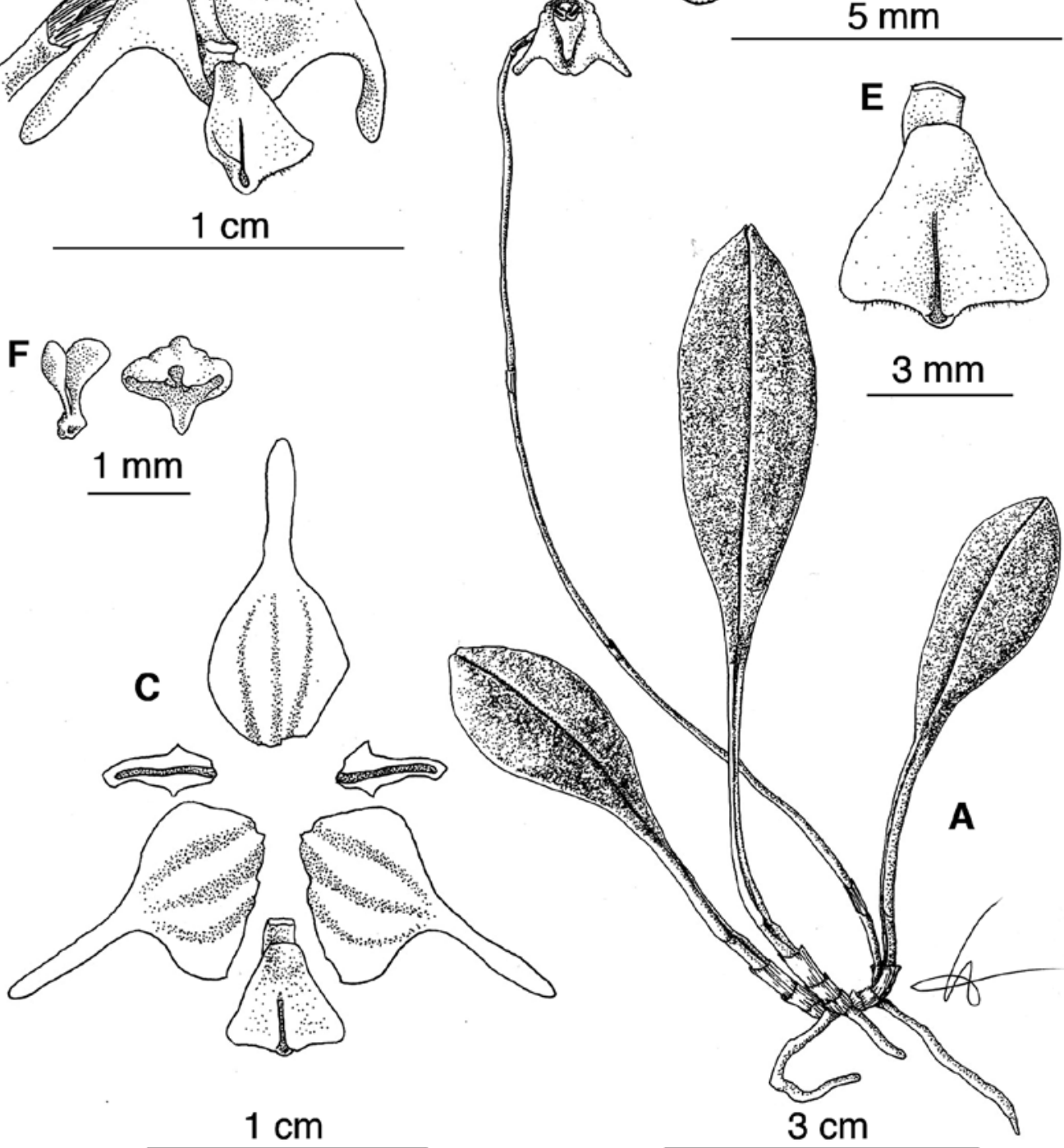


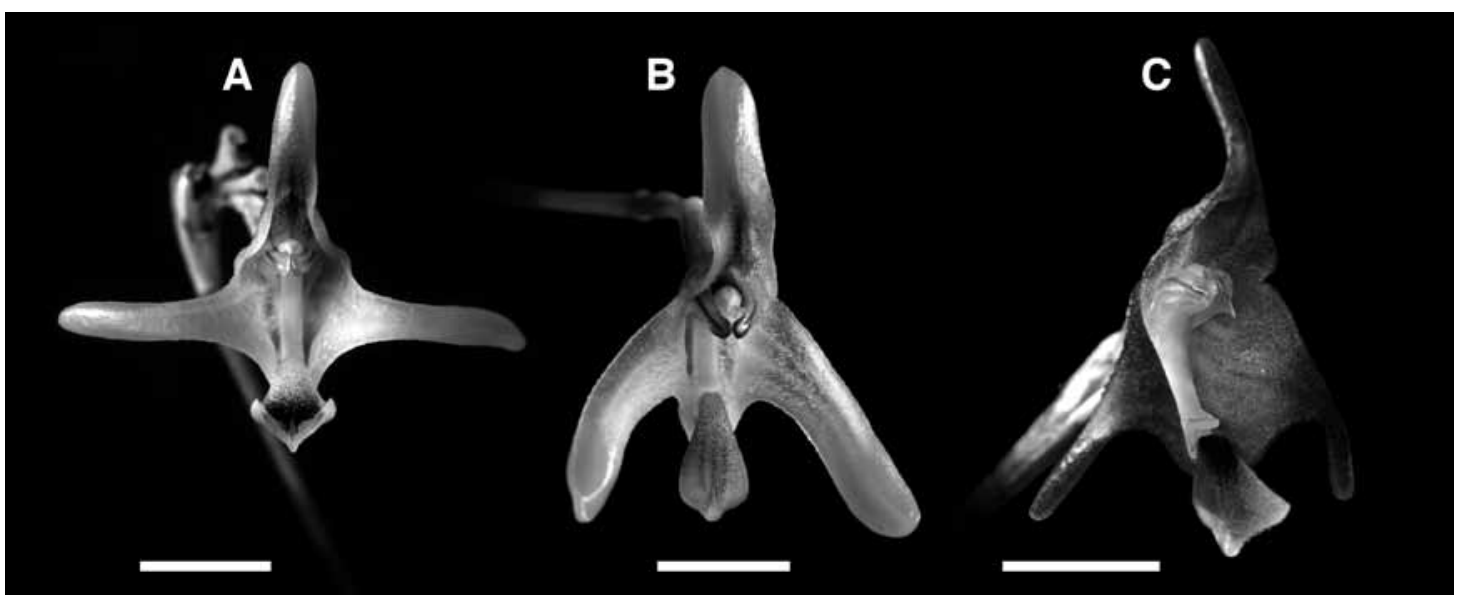

Figure 4. Pictures of holotype flowers of three new Porroglossum species. A - Porroglossum miguelangelii-.. B - P. merinoi. $\mathrm{C}-P$. porphyreum. Scale bars $=5 \mathrm{~mm}$. Photographs by F. Pupulin.

Porroglossum porphyreum G.Merino, A.Doucette \& Pupulin, sp. nov.

TYPE: EcuADOR. Morona-Santiago: El Aguacate, 1600 m, collected by Jinsop Medina, 1992, cultivated by Ecuagenera Orchid Nursery in Gualaceo, flowered in cultivation, 20 July 2008, G. Merino 3 (holotype: QCNE; isotype: CIOA, Spirit Collection No. 000743). Fig. 3, 4C.

A Porroglosso schramii Luer caudis sepalorum brevioribus incrassatis, sepalis lateralibus transverse ellipticis cauda apicali abrupte instructis, petalis dente acuto margo inferno munitis, labello toto dense pubescenti callo basali magno latiore recedit.

Herb epiphytic, caespitose. 6 to $10 \mathrm{~cm}$ tall. Roots flexuous, $1 \mathrm{~mm}$ in diameter. Ramicauls terete, erect, abbreviated, blackish at the base, 3--5 $\mathrm{mm}$ long, enclosed by 2 to 3 tubular, membraenous sheaths that become papery with age. Leaf coriaceous, ellipticobovate, obtuse to acute, $3-5 \times 1.5-2.0 \mathrm{~cm}$, narrowed at the base into a conduplicate petiole $1--3 \mathrm{~cm}$ long. Inflorescence a congested, successively, few flowered raceme; the peduncle terete, slender, glabrous, 10-12 $\mathrm{cm}$ long. Floral bract tubular, $4 \mathrm{~mm}$ long. Pedicel $5 \mathrm{~mm}$ long. Ovary terete, minutely verrucose, 6-sulcate, $6 \mathrm{~mm}$ long. Flowers resupinate, held erect to horizontally, without apparent fragrance, the sepals yellowish white heavily suffused with purple, the petals amber with a brown mid-vein, the lip white suffused with purple, the column and the anther cap white. Dorsal sepal ovate, acute, concave, tricarinate, $6 \times 3 \mathrm{~mm}$, contracted at apex into an erect to forward projecting, thickened, linear tail, connate to lateral sepals for about $4 \mathrm{~mm}$, the tails $1 \mathrm{~mm}$ in diameter. Lateral sepals ovate, slightly compressed, tricarinate, $10 \times 5 \mathrm{~mm}$ wide when spread, connate at the base for about $7 \mathrm{~mm}$, abruptly contracted at apex into thickened tails that may project forwards or slightly reflex backwards . Petals subfalcate, truncate, $4 \times 2 \mathrm{~mm}$, the margins present two triangular teeth below the middle. Lip entire, obcuneate, $4 \times 5 \mathrm{~mm}$ at its widest portion, hinged by a short rectangular strap to the column foot, motile, microscopically pubescent, with a sulcus running from the apex to the center of the lip, the base with a low, broad callus. Column short, stout, semiterete, fleshy, $3 \mathrm{~mm}$ long, with two tooth-like processes close to the stigma. Anther cap transversely ovate, obtuse-apiculate. Pollinia droplet shapped, 2 in number, each with a glandular caudicle.

PARATYPes: Same locality as the holotype, flowered in cultivation at Ecuagenera Orchid Nursery in Gualaceo, 10 December 2008, accession No. CIOA001373 (Centro de Investigación en Orquídeas de los Andes-Spirit); accession No. CIOA-001374 (Centro de Investigación en Orquídeas de los Andes-Spirit).

Etymology: From the Greek porphyreos, purple, in allusion to the color of the flower.

DisTRIBUTION: Known only from southeastern Ecuador. 
Habitat And ecology: Plants of $P$. porphyreum grow as shade epiphytes on the moss covered branches of shrubs, in the premontane forests of southern Andean Ecuador. In its natural habitat, $P$. porphyreum has been observed in flower from March to July; plants in cultivation flower most of the year.

Porroglossum porphyreum is similar to $P$. schramii Luer. P. porphyreum can be distinguished fromP. Schramii by having sepals that abruptly (rather than gradually) contract into thickened (rather than thin) sepaline tails. The petals of $P$. porphyreum have teeth below the middle on both margins while the petals of $P$. schramii only bear a tooth margin on the upper margin. The labellum of $P$. porhpyreum has a basal callus that is longer and broader than the basal callus of P. schramii.

ACKnowledgements. We acknowledges José Portilla Andrade and his family for granting access and use of the vast orchid collections at Ecuagenera, as well as for the many facilities they made available at Gualaceo for orchid research. This paper is part of the project No. 814A7-015, "Inventario y taxonomía de la flora epífita de la región Mesoamericana", supported by the Vice-Rectory of Research, University of Costa Rica.

\section{LiTERATURE CITED}

Bean, W. 1887. A sensitive Masdevallia. Gard. Chron. 1: 836.

Dodson, C.H. 2004. Native Ecuadorian Orchids. 4:822831.

Leavitt, R. G. 1906. The blooming of an unusual orchid. The Plant World. 9: 75-80.

Luer, C. A. 1980. Miscellaneous New Species in the
Pleurothallidinae (Orchidaceae). Phytologia. 46(6): 374-381.

Luer, C. A. 1985. Porroglossum hoeijeri Luer. Orchideen 6(1): 7.

Luer, C. A. 1987. Systematics of the genus Porroglossum. Monogr. Syst. Bot. Missouri Bot. Gard. 24: 25 —90.

Luer, C. A. 1988. Addenda to Porroglossum. Monogr. Syst. Bot. Missouri Bot. Gard. 26: 108 - 109.

Luer, C. A. 1989. Addendum to Porroglossum. Monogr. Syst. Bot. Missouri Bot. Gard. 31: 124-125.

Luer, C.A. 1991. Addenda to Porroglossum. Monogr. Syst. Bot. Missouri Bot. Gard. 39: 152-156.

Luer, C. A. 1994. Addenda to Porroglossum. Monogr. Syst. Bot. Missouri Bot. Gard. 52: 134.

Luer, C. A. 1995. Addenda to Porroglossum. Monogr. Syst. Bot. Missouri Bot. Gard. 57: 144.

Luer, C. A. 1998. Addenda to Porroglossum. Monogr. Syst. Bot. Missouri Bot. Gard. 72: 114-115.

Luer, C.A. 2000. Jostia: a new genus in the Pleurothallidinae. Monogr. Syst. Bot. Missouri Bot. Gard. 79: 1-4.

Luer, C. A. 2006a. Addendum to Porroglossum. Monogr. Syst. Bot. Missouri Bot. Gard. 95: 239.

Luer, C. A. 2006b. Addenda to Porroglossum. Monogr. Syst. Bot. Missouri Bot. Gard. 105: 253-254.

Schlechter, R. 1920. Beschreibungen neuer Arten: Porroglossum colombianum. Repert. Spec. Nov. Regni Veg. Beih. 7: 83.

Sweet, H. R. 1970. Orquídeas Andinas Poco Conocidas. Orquideologia 5: 166.

Sweet, H. R. 1972. The Genus Porroglossum. Amer. Orchid Soc. Bull. 41: 519.

Oliver, F. W., 1888. On the sensitive labellum of Masdevallia muscosa Rchb. f. Ann. Bot. (London) 1: 237-253.

Pridgeon, Alec M., Rodolfo Solano and Mark W. Chase. 2001. Phylogenetic relationships in Pleurothallidinae (Orchidaceae): combined evidence from nuclear and plastid DNA sequences. American Journal of Botany. 88:2286-2308. 